\title{
HUMAN RIGHTS PROTECTION FOR INDONESIAN MIGRANT WORKERS: CHALLENGES FOR ASEAN*
}

\author{
Winsherly Tan** dan Rina Shahriyani Shahrullah***
}

Bussiness Law Departement

Faculty of Law Universitas Internasional Batam

Jalan. Gajah Mada, Baloi Sei Ladi Kota Batam, Kepulauan Riau, 29442

\begin{abstract}
The AEC is good news for Indonesian migrant workers wanting to work overseas. Unfortunately, many Indonesian migrant workers have been deported from ASEAN countries because of having problems. This study adopts the normative legal research method. It argues that AICHR may be slow in resolving the problems of human rights, lack of commitment of ASEAN leaders to implement the Cebu Declaration. Therefore, the best solution is public participation in the ASEAN countries to protect migrant workers.
\end{abstract} Keywords: human rights, Indonesian Migrant Workers, ASEAN.

\section{Intisari}

Komunitas Masyarakat Ekonomi ASEAN adalah berita baik untuk Tenaga Kerja Indonesia untuk bekerja di luar negeri. Namun, banyak tenaga kerja yang kembali dari negara ASEAN dikarenakan mendapatkan berbagai permasalahan. Penelitian ini mengadopsi penelitian hukum normatif. Penelitian ini menyimpulkan bahwa AICHR lamban dalam menyelesaikan permaslahan tentang hak asasi manusia. tidak adanya komitmen politik dari para pemimpim ASEAN dalam menerapkan Deklarasi Cebu. Oleh sebab itu, dibutuhkan partisipasi ASEAN dalam melindungi TKI.

Kata Kunci: HAM, Tenaga Kerja Indonesia, ASEAN.

\section{Pokok Muatan}

A. Background 124

B. Research Method

C. Research Findings and Analysis 128

1. Are Indonesian Legal Instruments Sufficient to Give Human Rights Protection to Migrant Workers?

2. Are ASEAN Regulations Sufficient to Give Human Rights Protection to Migrant Workers?

D. Conclusion

This article was presented at the International Postgraduate Legal Research Conference 2015 at the University of Malaya, Malaysia on 24 March 2015 to obtain input for publication.

** Correspondence Address : winsherly123@gmail.com

**** Correspondence Address : rina@uib.ac.id. 


\section{A. Background}

At the 12th ASEAN Summit in January 2007

in Cebu, the Philippines, the ASEAN Leaders were committed to accelerating the establishment of an

ASEAN Economic Community (AEC) by 2015, as envisioned in the ASEAN Vision 2020, ${ }^{1}$ which clearly stipulates:

We envision our rich human and natural resources contributing to our development and shared prosperity. [...] We commit ourselves to moving towards closer cohesion and economic integration, narrowing the gap in the level of development among Member Countries, ensuring that the multilateral trading system remains fair and open, and achieving global competitiveness. [...] We will create a stable, prosperous and highly competitive ASEAN Economic Region in which there is a free flow of goods, services and investments, a freer flow of capital, equitable economic development and reduced poverty and socioeconomic disparities.

The AEC 2015 establishes ASEAN as a single market and transforms ASEAN into a region with free movement of goods, services, investment, skilled labour, and freer flow of capital. ${ }^{2}$ The free flow of skilled labour raises a crucial challenge for ASEAN member states since each member state has different migration policies. To respond to this challenge, all ASEAN member states should 'align their governance and management of labour migration with international and regional obligations, guidance, and best practice'. ${ }^{3}$

To Indonesian migrant workers, the AEC is perceived as "good news" for them to realize their dream to "freely work overseas". Indonesia is the biggest migrant worker sending country. It is the fourth largest country in the world, with an estimated population of 226 million and an annual population growth rate of 1.24 percent. The labour force of Indonesia consists of over 115 million people, whereas work places remain limited. ${ }^{4}$ This condition is one of the motivations for many Indonesians wishing to work overseas.

Since the 1990s, the Indonesian Government has established a clear labour migration policy pertaining to Indonesian overseas workers. By 2006, statistics suggested that there were 712,160 Indonesian migrants formally deployed to work overseas, and over three-quarters of them were female. ${ }^{5}$

Indonesia as a sending country has sent its workers to various countries. Based on data from the National Agency for the Placement and Protection of Indonesian Overseas Workers (BNP2TKI), the number of migrant workers overseas has been as follows:

Table 1.

Placement of Workers Based on Gender (1 January-31 October 2014)

\begin{tabular}{lllll}
\hline No & $\begin{array}{l}\text { Placement } \\
\text { Migrant } \\
\text { Country }\end{array}$ & \multicolumn{2}{c}{ Gender } & Total \\
& Male & Female & \\
\hline 1 & Malaysia & 67,697 & 39,388 & 107,085 \\
2 & Taiwan & 20,103 & 48,771 & 68,874 \\
3 & Saudi Arabia & 19,535 & 18,569 & 38,104 \\
4 & Hong Kong & 871 & 29,337 & 30,208 \\
5 & Singapore & 3,423 & 22,178 & 25,601 \\
6 & United Arab & 2,050 & 13,226 & 15,276 \\
& Emirates & & & \\
7 & Oman & 220 & 14,815 & 15,035 \\
8 & South Korea & 9,419 & 204 & 9,623 \\
9 & Brunei & 5,773 & 3,525 & 9,298 \\
& Darussalam & & & \\
10 & The United & 7,391 & 448 & 7,839 \\
& States & & & \\
\hline
\end{tabular}

Source: BNP2TKI, 1 January - 31 October 2014.

The favorite countries of destination for Indonesian migrants are Hong Kong, Kuwait,

ASEAN, “ASEAN Economic Community Blueprint”, www.asean.org/archive/5187-10.pdf., accessed 8 September 2014.

Ibid.

UN Women, "Managing Labour Migration in ASEAN: Concerns for Women Migrant Workers", http://asiapacific.unwomen.org., accessed 8 September 2014

Mahidol Migration Centre, “Migrant Workers' Right to Social Protection in ASEAN: Case Study of Indonesia, the Philippines, Singapore and Thailand", http://www.ilo.org, accessed 8 September 2014.

Suchita Manajit and Mai Thi Thanh Nga Na, 2011, Migrant Workers Rights to Social Protection in ASEAN (Case Studies of Indonesia, Philippines, Singapore and Thailand), Friedrich-Ebert-Stiftung, Pamplona, pp. 37-38. 
Malaysia, Saudi Arabia, Singapore, South Korea and Taiwan. Most migrant workers from Indonesia work overseas in low-skilled or semi-skilled occupations, such as agriculture, construction and manufacturing. The majority of Indonesian women migrant workers are employed as domestic workers or caregivers. ${ }^{6}$ Migrant workers from Indonesia make an important economic contribution to the country due to the amount of foreign remittances sent home. According to the Bank of Indonesia, remittances from Indonesian workers abroad reached US $\$ 6.6$ billion in 2008, and this figure is projected to steadily increase over time.?

Data below show the number of migrant workers based on the countries of destination.

Table 2.

Placement of Migrant Workers Per Year Per Country

\begin{tabular}{|c|c|c|c|c|c|c|c|c|c|}
\hline \multirow{2}{*}{ No } & \multirow{2}{*}{$\begin{array}{l}\text { Placement } \\
\text { Countries }\end{array}$} & \multicolumn{7}{|c|}{ Year } & \multirow{2}{*}{ Total } \\
\hline & & 2006 & 2007 & 2008 & 2009 & 2010 & 2011 & 2012 & \\
\hline 1 & Saudi Arabia & 281,087 & 257,217 & 234,644 & 276,633 & 228,890 & 137,643 & 11,814 & $1,427,928$ \\
\hline 2 & Malaysia & 219,658 & 222,198 & 187,123 & 123,886 & 116,056 & 134,108 & 46,296 & $1,049,325$ \\
\hline 3 & Taiwan & 45,706 & 50,810 & 59,522 & 59,335 & 62,048 & 73,498 & 30,669 & 381,588 \\
\hline 4 & $\begin{array}{l}\text { Singapore } \\
\text { United }\end{array}$ & 28,661 & 37,496 & 21,807 & 33,077 & 39,623 & 47,781 & 20,430 & 228,875 \\
\hline 5 & $\begin{array}{l}\text { Emirate Arab } \\
\text { (Uea) }\end{array}$ & 22,685 & 28,184 & 38,092 & 40,391 & 37,337 & 39,857 & 14,274 & 220,820 \\
\hline 6 & Hong Kong & 20,100 & 29,973 & 30,204 & 32,417 & 33,262 & 50,283 & 18,237 & 214,476 \\
\hline 7 & Kuwait & 24,600 & 25,756 & 29,218 & 23,041 & 563 & 2,723 & 693 & 106,594 \\
\hline 8 & Qatar & 7,980 & 10,449 & 8,582 & 10,010 & 13,559 & 16,578 & 8,476 & 75,634 \\
\hline 9 & Yordania & 10,978 & 12,062 & 11,155 & 10,932 & 5,695 & 134 & 29 & 50,985 \\
\hline 10 & Oman & 5,210 & 7,150 & 8,309 & 9,700 & 9,259 & 7,292 & 3,375 & 50,295 \\
\hline 11 & $\begin{array}{l}\text { Brunai } \\
\text { Darussalam }\end{array}$ & 8,482 & 5,852 & 3,861 & 4,785 & 7,360 & 10805 & 5,703 & 46,848 \\
\hline 12 & Korea Selatan & 4,035 & 3,830 & 8,134 & 1,890 & 7,596 & 11,390 & 6,399 & 43,274 \\
\hline 13 & $\begin{array}{l}\text { Amerika } \\
\text { Serikat }\end{array}$ & - & 1,263 & 66 & 47 & 475 & 13,746 & 5,088 & 20,685 \\
\hline 14 & Bahrain & 639 & 2,267 & 2,324 & 2,837 & 4,844 & 4,375 & 2,832 & 20,118 \\
\hline 15 & Syria & - & - & - & 1,155 & 6,381 & 4222 & 1 & 11,759 \\
\hline 16 & Italia & - & 953 & 7 & - & 13 & 3,408 & 1,765 & 6,146 \\
\hline 17 & Jepang & 36 & 96 & 232 & 362 & 233 & 2,508 & 1,441 & 4,908 \\
\hline 18 & Aljazair & - & - & 499 & 453 & 609 & 1,084 & 563 & 3,208 \\
\hline 19 & Afrika Selatan & - & 111 & - & - & 12 & 2,009 & 786 & 2,918 \\
\hline 20 & Macao & - & 164 & 468 & 674 & 826 & 582 & 148 & 2,862 \\
\hline 21 & Spanyol & - & 210 & 4 & - & 10 & 1484 & 693 & 2,401 \\
\hline 22 & $\mathrm{RRC}$ & - & - & - & - & - & 1072 & 645 & 1,717 \\
\hline 23 & Thailand & - & - & - & 9 & 1 & 1113 & 426 & 1,549 \\
\hline 24 & Turki & - & - & 6 & - & 25 & 1016 & 352 & 1,399 \\
\hline 25 & New Zealand & - & - & 71 & 269 & 279 & 468 & 212 & 1,299 \\
\hline 26 & Fiji & - & - & - & - & - & 556 & 447 & 1,003 \\
\hline 27 & Maldives & - & - & 22 & 20 & 80 & 638 & 185 & 945 \\
\hline 28 & Australia & - & - & 5 & - & 1 & 526 & 363 & 895 \\
\hline 29 & Nigeria & - & - & 82 & 81 & 9 & 588 & 88 & 848 \\
\hline 30 & Mauritius & - & - & - & - & 3 & 478 & 359 & 840 \\
\hline
\end{tabular}




\begin{tabular}{|c|c|c|c|c|c|c|c|c|c|}
\hline 31 & Brasil & - & - & - & - & 66 & 313 & 446 & 825 \\
\hline 32 & Belanda & - & 10 & 3 & - & 1 & 592 & 202 & 808 \\
\hline 33 & India & - & - & - & 2 & 12 & 519 & 236 & 769 \\
\hline 34 & Lain-lain & 143 & 554 & - & - & - & 17 & - & 714 \\
\hline 35 & Uruguay & - & - & - & - & - & 496 & 195 & 691 \\
\hline 36 & Cyprus & - & - & 1 & - & 37 & 356 & 295 & 689 \\
\hline 37 & Jerman & - & 10 & 3 & - & 1 & 299 & 354 & 667 \\
\hline 38 & Inggris & - & 8 & - & - & 6 & 491 & 119 & 624 \\
\hline 39 & Trinidad & - & - & - & - & - & 213 & 382 & 595 \\
\hline 40 & $\begin{array}{l}\text { Papua New } \\
\text { Guini }\end{array}$ & - & - & - & - & - & 309 & 239 & 548 \\
\hline 41 & Vietnam & - & - & - & - & - & 337 & 179 & 516 \\
\hline 42 & Libya & - & - & 114 & 35 & 251 & 83 & 3 & 486 \\
\hline 43 & Timor Leste & - & - & 3 & - & - & 425 & 35 & 463 \\
\hline 44 & Swiss & - & - & - & - & - & 174 & 277 & 451 \\
\hline 45 & Mesir & - & - & - & 2 & 13 & 265 & 130 & 410 \\
\hline 46 & Peru & - & - & - & - & - & 301 & 105 & 406 \\
\hline 47 & Portugal & - & - & - & - & 5 & 248 & 117 & 370 \\
\hline 48 & Yaman & - & 123 & 90 & 30 & 7 & 59 & 59 & 368 \\
\hline 49 & Rusia & - & - & - & - & 2 & 246 & 106 & 354 \\
\hline 50 & Perancis & - & - & - & - & 117 & 153 & 81 & 351 \\
\hline 51 & Lain-lain & - & - & 80 & 99 & 236 & 3,220 & 1,710 & 5,345 \\
\hline \multicolumn{2}{|c|}{ Total } & 680,000 & 696,746 & 644,731 & 632,172 & 575,803 & 581,081 & 188,059 & $3,998,592$ \\
\hline
\end{tabular}

Source: BNP2TKI.

Table 3.

Indonesian Migrants and Top Destination

Countries (1 January-31 October 2014)

\begin{tabular}{clc}
\hline No & Destination Countries & Total \\
\hline 1 & Malaysia & 107,085 \\
2 & Taiwan & 68,874 \\
3 & Saudi Arabia & 38,104 \\
4 & Hong Kong & 30,208 \\
5 & Singapore & 25,601 \\
6 & United Arab Emirates & 15,276 \\
7 & Oman & 15,035 \\
8 & South Korea & 9,623 \\
9 & Brunei & 9,298 \\
10 & The United States & 7,839 \\
\hline
\end{tabular}

Source: BNP2TKI.

Based on this data, ASEAN member states are categorized as the favorite destinations of Indonesian migrant workers. Unfortunately, many Indonesian migrant workers have been deported from several ASEAN states because of having problems while working in those states. Indonesian overseas migrant workers who are returned to Indonesia because of having problems are referred to as "Troubled Indonesian Migrant Workers" (Tenaga Kerja Indonesia Bermasalah/TKIB). Data from BNP2TKI below show the number of TKIB.

Table 4.

Number of Deported Troubled Indonesian Migrant Workers (2006-2014)

\begin{tabular}{cccc}
\hline Year & Return & $\begin{array}{c}\text { Troubled Mi- } \\
\text { grant Workers }\end{array}$ & Percentage \\
\hline 2006 & 376,782 & 57,971 & 15.4 \\
2007 & 354,921 & 58,085 & 16.4 \\
2008 & 447,016 & 50,765 & 11.4 \\
2009 & 492,073 & 53,168 & 10.8 \\
2010 & 539,169 & 95,060 & 14.4 \\
2011 & 494,266 & 72,194 & 14.7 \\
2012 & 393,720 & 47,620 & 12.9 \\
2013 & 260,093 & 44,087 & $13.6^{-}$ \\
2014 & 201,779 & 30,661 & 15.1 \\
\hline
\end{tabular}

Source: BNP2TKI. 
BNP2TKI states that the following are the most frequent reasons for TKIB returning to Indonesia.

Table 5.

\section{Reasons for Returning to Indonesia}

\begin{tabular}{clc}
\hline No & $\begin{array}{l}\text { Type of Migrant Worker } \\
\text { Case }\end{array}$ & Percentage \\
\hline 1 & Salary not paid & 45.50 \\
2 & Abuse/physical violence & 9.93 \\
3 & Sexual harassment & 3.99 \\
4 & Workload does not suit & 10.01 \\
5 & Employer is not compatible & 16.26 \\
6 & Working hours are not suitable & 0.16 \\
7 & Feels uncomfortable & 2.35 \\
8 & Dispute & 0.39 \\
9 & Illness & 11.42 \\
\hline
\end{tabular}

Source: Direktorat Perlindungan WNI dan BHI, 2011.

Based on the background described above, the author proposes two (2) questions as follows: (1) Are the rights of Indonesian Migrant Workers (TKI) protected under Indonesian Law? ; (2) Are the rights of Indonesian Migrant Workers (TKI) protected by ASEAN Regulations?

\section{B. Research Method}

In carrying out this research, the author used a type of normative legal research which is a conceptual study of law as it exists in the legislation.

\section{Types of Research}

This paper is based on normative legal research, done by reviewing the laws and regulations that apply to a specific legal issue. In conducting this research the author used secondary data obtained from Law No. 39 of 2004 on the Placement and Protection of Migrant Workers Abroad, regulations in the ASEAN community regarding the protection of migrant workers' rights and other legislation.

According to Marzuki, normative legal research is the research of law whereby the objects are legislations and other materials. Therefore, normative research is often referred to as doctrinal research. ${ }^{8}$ Normative legal research can also be divided into several types. Soerjono Soekanto has split it into the following kinds of legal research: ${ }^{9}$ (1) Research into the principles of law; (2) Research into the systems of law; (3) Research into the synchronization of law; Research into the history of law.

\section{Types of Data}

In normative legal research, the data acquired and processed are types of secondary legal materials, which in this study are used as the primary legal materials, the data obtained from the literature. ${ }^{10}$

The type of data used in this study was in the form of primary, secondary and tertiary data, including:

a. Primary legal materials are binding law, such as legislation. According to Marzuki, primary legal materials are authoritative legal sources. They comprise legislation, official records, minutes in the making of laws and regulations. ${ }^{11}$ In this research, the author uses primary legal materials as follows: (1) The 1945 Constitution of the Republic of Indonesia; (2) Law No. 39 of 2004 on the Placement and Protection of Migrant Workers Abroad; (3) The ASEAN Charter; (4) The InterGovernmental Commission on Human Rights (AICHR); (5) The ASEAN Commission on the Promotion and Protection of the Rights of Women and Children; (6) The ASEAN Human Rights Declaration; (7) The ASEAN Committee on the Implementation of the ASEAN Declaration on the Protection and Promotion of the Rights

\footnotetext{
Soerjono and H. Abdurahman, 2006, Metode Penelitian Hukum, Rineka Cipta, Jakarta, p. 56. Bambang Sunggono, 2003, Metodologi Penelitian Hukum, Raja Grafindo Persada, Jakarta, p. 42.

Soerjono and H. Abdurahman, Op.cit., p. 57.

Marzuki, Op.cit., p. 141.
} 
of Migrant Workers.

b. Secondary law materials are legal materials that support and strengthen the primary legal materials, by providing an explanation of the primary legal materials available to allow analysis and deeper understanding. The secondary legal materials used consisted of: ${ }^{12}$ (1) Explanations of legislation used as primary legal materials; (2) Modules sourced from the Ministry of Foreign Affairs and the ASEAN Secretariat regarding the protection of migrant workers' rights; (3) Research results relating to the protection of human rights of Indonesian workers who work abroad; (4) Competent expert opinion from investigator study; (5) Articles or posts from experts; (6) Electronic means of discussing related issues.

\section{Data Collection Techniques}

In this study, the data used by the writer as the primary data were interviews with the director of the Woman Viva World Foundation, a TKI shelter located in Batam, and asking questions of Mr Refendi Djamis as the Indonesian representative to AICHR regarding Indonesia migrant workers. Secondary data included using the techniques of data collection, expert opinion from various law books, journal reports, as well as agreements and regulations in the ASEAN community regarding the promotion and protection of human rights.

\section{Method of Data Analysis}

Bogdan and Taylor define qualitative methodology as follows: ${ }^{13}$

"Research procedure produces descriptive data in the written and spoken forms of the people and in behaviors that can be observed. In other words, the research called for a qualitative research."
According to Djajasudarma, qualitative methodology is defined as follows: ${ }^{14}$

"Qualitative research should consider qualitative methodology itself. Methodology is a procedure that produces descriptive data in the form of data in a written or spoken language community."

\section{Research Findings and Analysis \\ 1. Are Indonesian Legal Instruments Sufficient to Give Human Rights Protection to Migrant Workers?}

Indonesia already has several laws to protect Indonesian citizens who work abroad. The 1945 Constitution (UUD 1945) under Article 27 (2) stipulates, "Every citizen has the right to employment and decent living for humanity". Article 28D (2) of the 1945 Constitution states, "Everyone has the right to work and obtain remuneration and fair and reasonable treatment in relation to their employment". In addition, Article 31 of the 1945 Constitution emphasizes, "Every worker has the same rights and opportunities to choose, get or change jobs and earn a decent income inside or outside the country".

As a manifestation of the 1945 Constitution, the Indonesian Government passed Law No. 39 of 2004 concerning the Placement and Protection of Indonesian Workers Overseas. This law is the main statutory instrument related to social and legal protection for Indonesian overseas migrant workers. It sets out legal provisions pertaining to the placement procedures, such as pre-placement training, predeparture programs, health examinations, worker protection, dispute settlement, supervision of placement and protection activities for Indonesia overseas migrant workers.

More specifically, Presidential Instruction No. 6 of 2006 (INPRES 2006) was issued concerning Policy Reform on the Placement

Soerjono Soekanto and Sri Mamudi, 2003, Penelitian Hukum Normatif Suatu Tinjauan Singkat, Raja Grafindo Persada, Jakarta, p. 23

Bodgan dan Taylor sebagaimana dikutip dalam Universitas Udayana, "Tesis", http://www.pps.unud.ac.id/thesis/pdf_thesis/unud-1411791400890-bab\%20iii.pdf, accessed on 14 August 2013. 
and Protection System of Indonesian Overseas Migrant Workers. This INPRES regulates detailed actions to improve migrant placement services, the placement quality of migrants and to strengthen the function of Indonesian representatives in providing protection to Indonesian overseas migrant workers. In 2006, a national body to deal with issues relevant to the placement and protection of Indonesian migrant workers was established by Presidential Regulation No. 81 of 2006 on the Establishment of a National Body for the Placement and Protection of Indonesian Overseas Workers (BNP2TKI). The Regulation aims to improve the security, protection and empowerment of overseas migrant workers ${ }^{15}$. The Regulation was followed by the establishment of the Overseas Cooperation Agency (BKLN) based on Regulation No. 28 of 2007. This regulation is derived from $\mathrm{BNP} 2 \mathrm{TKI}$ and focuses on the obligation of employment agencies to provide protection and pre-placement training for prospective Indonesian migrant workers. ${ }^{16}$

Despite the legal protection for overseas migrant workers provided by Law No. 39 of 2004, it is apparent that the Law remains insufficient to protect migrant workers overseas. There are several weaknesses of both substance and implementation in Law No. 39 of 2004, as follows:

1. The Republic of Indonesia (RI) representatives' obligations in providing protection to Indonesian migrant workers are still formulated in a very general approach. Article 78 paragraph (1) of Law No. 39 of 2004 merely states that RI representatives shall provide protection for migrant workers abroad in accordance with the laws and regulations, as well as customary international law. Paragraph 2 of the said article does not explicitly require the need for the existence of an employment attaché at the Indonesian
Embassy. The relevant paragraph only states, that "in order to protect migrant workers abroad, the Government may appoint a Labor Attaché at Indonesian Embassy". Thus, in practice, the Embassy cannot provide optimal protection to Indonesian overseas migrant workers.

2. Article 13 paragraph (1)(e) requires employment agencies sending migrant workers overseas to obtain a licence for Executive Placement of Indonesian Workers (SIPPTKI). This provision obliges the Private Employment Agencies of Indonesian Migrant Workers (PPTKIS) to have their own training units and raises controversy in Indonesian society. These requirements discriminate against the PPTKIS because the establishment of a training unit requires substantial capital, yet there is no guarantee that the government will approve and issue it a permit. This is because, in addition to the training unit, there are many other requirements that must be met by a PPTKIS in order to obtain such a permit. Since many PPTKIS do not have a training unit, they usually collaborate with other parties (government or private training institutions) to conduct the training. It is argued that vocational training should be conducted by a separate organization from a PPTKIS to maintain the quality of the training itself. The reason for this is the job training provided by an independent institution can avoid the irregular job training that is sometimes given for the sake of administrative requirements.

3. Ajudicial review of Article 35 point (d) 
by the Constitutional Court eliminated the minimum education/training requirements for prospective workers. This poses a problem because most of the NGOs opine that the education requirement is important to reduce the level of abuse of migrant workers by certain parties (i.e. employers, PPTKIS).

The weaknesses of Law No. 39 of 2004 to provide sufficient legal protection to Indonesian migrant workers has caused many incidents involving the violation of human rights. Based on the data obtained by ANTARA (Indonesian News Office), in 2011 in Kuala Lumpur, there were 1001 cases of unpaid wages, 275 cases of disharmony between workers and employers, 51 cases of the exploitation of workers, 13 cases of unilateral layoffs and about 174 cases of job mismatching. ${ }^{17}$ Other cases were physical violence (57), human trafficking (59), pain or stress (52), abandoned or illegal (90), criminal acts (16), death (50) or accidents (15). ANTARA reported that in 2011, there were 1865 cases involving troubled Indonesian migrant workers. Employment-related cases (labor cases) were as many as 1514 and cases of non-employment (non-labour cases) were approximately $351 .{ }^{18}$ The following table shows some incidents experienced by Indonesian migrant workers in Malaysia. ${ }^{19}$

Table 6.

Indonesian Migrant Worker Cases

\begin{tabular}{|c|c|c|c|c|c|}
\hline No & $\begin{array}{l}\text { Name of } \\
\text { Worker }\end{array}$ & Place of Origin & $\begin{array}{l}\text { Place of } \\
\text { Work }\end{array}$ & Case & Year \\
\hline 1. & $\begin{array}{l}\text { Nirmala } \\
\text { Bonat }\end{array}$ & $\begin{array}{l}\text { Kupang, Nusa Tenggara } \\
\text { Timur (East Nusa } \\
\text { Tenggara) }\end{array}$ & Malaysia & $\begin{array}{l}\text { Tortured, splashed with hot/boiling } \\
\text { water, burned with a hot iron. }\end{array}$ & 2004 \\
\hline 2. & Ceriyati & $\begin{array}{l}\text { Brebes, Jawa Tengah } \\
\text { (Central Java) }\end{array}$ & Malaysia & $\begin{array}{l}\text { Tortured, escaped through a } 15 \text { th floor } \\
\text { apartment window. Body was covered } \\
\text { in wounds. Swellings on the forehead } \\
\text { and the right side of neck. Hand } \\
\text { injuries. }\end{array}$ & 2007 \\
\hline 3. & Siti Hajar & $\begin{array}{l}\text { Garut, Jawa Barat (West } \\
\text { Java) }\end{array}$ & Malaysia & $\begin{array}{l}\text { Tortured, splashed with hot water. } \\
\text { Seriously injured. Wounds on all parts } \\
\text { of the body. }\end{array}$ & 2009 \\
\hline
\end{tabular}

Source: Fathor Rahman, 2011.

Then, it is also supported by data from Director of the Woman Viva World Foundation. In this stage many of the problems that led to the violation of the rights of migrant workers abroad, according to Ayu as the director of the shelter workers who are located in the Batam city where migrant shelter is shaded by the World Foundation
Viva Woman, Ayu said that many workers who go to work abroad through illegal recruitment because of legal recruitment very slow which ultimately forced the migrant workers prefer illegal recruitment because it is faster and easier. When the recruitment process, there are also many documents of migrant workers who falsified in order to be accepted in the

\footnotetext{
17 ANTARA, "Kasus TKI Bermasalah Terbanyak Soal Gaji Tak Dibayar Majikan”, http://www.antarakl.com/index.php/naker/1103-kasus-tkibermasalah-terbanyak-soal-gaji-tak-dibayar-majikan, accessed on 28 December 2014. 
receiving country of migrant. In order to be able to work abroad, the prospective migrant workers are willing to pay money amounting to Rp. 100,000 or Rp. 120,000 to make identity cards which they change their age and even their names. ${ }^{20}$

Most of the government's response to abuse of Indonesian domestic workers in other countries has focused on improving the training, with the main emphasis on language skills and their work. ${ }^{21}$ Ayu explained that many acts of violence committed by the employer caused the worker does not have the expertise or knowledge as had never been trained from the sender agent. ${ }^{22}$ For example, there are workers who work as domestic servants, she does not know how to cook rice using rice cooker, do not know how to scold a washing machine that finally makes the employer angry and commit acts of violence. ${ }^{23}$

Based on Human Rights Watch interviewed with Indonesian migrant workers indicate that many employment agencies do not provide programs pre-departure orientation, even confiscate the belongings of the workers and their contact info, and deceiving them about the rights and obligations in Malaysia. Competition between employment agencies to send domestic workers to Malaysia as soon as their documents is processed can lead them to leave the steps such as providing pre-departure orientation required. ${ }^{24}$

The Indonesian government continues to allow recruiters (agency), to manage most of the recruitment and training process that ultimately unsupervised implementation of Law no. 39 of 2004 and the protection of migrant workers' rights set forth in Article 8 of Law no. 39 of 2004 and the rights of migrant workers in the 1945 Constitution would never have done well on the field when it's clearly stated in article 7 point $b$ and point $d$, one responsibility of government is to oversees the implementation of prospective TKI placement and to provide the protection of TKI, for a time prior to departure, deployment, and after-deployment time.

\section{Are ASEAN Regulations Sufficient to} Give Human Rights Protection to Migrant Workers?

Incidents and human rights violations suffered by Indonesian migrant workers in ASEAN member countries constitute a major challenge for the ASEAN Community 2015 in dealing with human rights violations. The ASEAN Community 2015 consists of three pillars, namely: (1) the ASEAN Political-Security Community; (2) the ASEAN Economic Community; (3) the ASEAN Socio-Cultural Community, which should be used as a platform to strengthen effective collaboration among ASEAN member states to tackle human rights violations against overseas migrant workers.

The ASEAN Intergovernmental Commission on Human Rights (AICHR) was established on October 23, 2009. It has 14 mandates and functions, including the promotion and protection of human rights; undertaking cooperative action and dialogue, being informative and consultative, carrying out thematic studies, and preparing an annual report. One of the AICHR mandates is to implement the ASEAN Human Rights Declaration, which was signed by the leaders of ASEAN countries at the ASEAN Summit on November 18-19, 2012 in Phnom Penh, Cambodia. ${ }^{25}$

Nevertheless, handling violations of human rights in ASEAN is not easy. The presence of the AICHR does not mean the human rights violations can automatically be resolved. This is because the AICHR is slow in resolving the problems of human rights in the ASEAN region. The implementation of the AICHR brings it face-to-face with the ASEAN principle of non-intervention. Based on this principle, each ASEAN member state is prohibited

\footnotetext{
Ibid.

24 Human Rights Watch, “Abuses against Female Migrant Domestic Workers in Indonesia and Malaysia”, http://www.hrw.org/reports/2004/07/21/ help-wanted, accessed 8 September 2014

25 Kalayamitra, "Mekanisme HAM di ASEAN: Peluang Penegakan HAM di Tingkat Regional", http://www.kalyanamitra.or.id/2013/02/ mekanisme-ham-di-asean-peluang-penegakan-ham-di-tingkat-regional/, accessed on 6 February 2014.
} 
from interfering in the domestic problems of another ASEAN member state. As a result, the AICHR can only initiate dialogues among ASEAN member states. In addition, the AICHR is given authority to impose sanctions on ASEAN member states which violate human rights.

Asidefromsuchweaknesses, theestablishment of the AICHR is a progressive step towards ASEAN realizing its objectives, namely to strengthen democracy, enhance good governance and the rule of law, and to promote and protect human rights and fundamental freedoms. The violence against migrant workers in ASEAN member states is one of the human rights situations that needs special attention at the regional level. The Foreign Ministers of the 10 ASEAN countries agreed to form a Committee on the Implementation of the ASEAN Declaration on the Protection and Promotion of the Rights of Migrant Workers at the 12th ASEAN Summit in Cebu, the Philippines in 2007. The purpose of this committee is to (1) promote policies and programs to protect the rights of migrant workers in sending and receiving countries; (2) encourage international organizations, dialogue partners of ASEAN and other countries to respect the principles and extend support and assistance for the implementation of the measures contained in the Declaration; (3) promote harmonization between the sending countries and the mechanisms that protect and promote the rights of migrant workers. ${ }^{26}$

The ASEAN Committee on Migrant Workers is expected to make slow progress in the absence of the political commitment of the ASEAN leaders to implement the Cebu Declaration on the Protection and Promotion of the Rights of Migrant Workers. ${ }^{27}$ In addition, public participation in the ASEAN region is needed to support the work of the ASEAN Committee on Migrant Workers. NonGovernmental Organizations (NGOs) and other
Civil Society Organizations (CSOs) in the ASEAN member states should seriously address the issue of migrant workers, including Indonesian migrant workers. Best practices have been conducted through an MoU between BNP2TKI and the International Organization on Migration (IOM) Indonesia. This collaboration has received support from the Ministry of Manpower (Manpower) and the United Nations Entity for Gender Equality and Empowerment of Women (UN Women). The main objective of this cooperation program is to increase the capacity of government institutions to promote labor recruitment practices abroad.

Public participation among the ASEAN member states has been conducted by Indonesian and Malaysian advocates in dealing with cases of violence against Indonesian migrant workers in Malaysia. The Indonesian Advocates' Association has established cooperation with bar associations in Malaysia to provide protection and legal assistance for workers who are mistreated by their employers in Malaysia. The DIVA Women's Foundation, an NGO in Batam, has been actively collaborating with a Singaporean NGO, Humanitarian Organization for Migration Economics (Singapore HOME), in assisting troubled migrant workers when they are deported from Singapore to Batam. The migrant workers are accommodated in the shelter of DIVA Women's Foundation.

\section{Conclusion}

Indonesia as a sender country for migrant workers overseas, especially in Southeast Asian countries, Indonesia government has made some rules or laws in order to protect the rights of migrant workers while working abroad in many of the provisions contained in the 1945 Constitution. More specific regulation that protecting of migrant workers' rights is Law No. 39 of 2004 but there

\footnotetext{
26 ASEAN, "Statement of the Establishment of the ASEAN Committee on the Implementation of the ASEAN Declaration on the Protection and Promotion of the Rights of Migrant Workers", http:/www.asean.org/communities/asean-political-security-community/item/statement-of-theestablishment-of-the-asean-committee-on-the-implementation-of-the-asean-declaration-on-the-protection-and-promotion-of-the-rights-ofmigrant-workers, accessed on 30 July 2007.

27 Migrantcare, "Nasib Buruh Migran di Regional ASEAN", http://www.migrantcare.net/mod.php?mod=publisher\&op=printarticle\&art $i d=1451$, accessed on 5 May 2014.
} 
are several weaknesses of the Law no. 39 of 2004 both in terms of substance and implementation. Based on the discussion above, it is apparent that the Indonesian legal instruments, which aim to protect Indonesian migrant workers, contain many weaknesses.

ASEAN has been producing various regulations regarding the promotion and protection of human rights primarily to protect the rights of migrant workers which is still a challenge for ASEAN to resolve many cases of violations of the rights of migrant workers that occurred in the ASEAN region itself such as the ASEAN Charter, Intergovernmental Commission on Human Rights (AICHR) and ASEAN Committee on the Implementation of the ASEAN Declaration on the Protection and Promotion of the Rights of Migrant Workers (ACMW).

Similarly, the ASEAN instruments for the protection of migrant workers cannot be fully imposed on ASEAN member states since they may be impeded by the non-intervention principle. In addition, there is no mechanism in ASEAN relating to the implementation of sanctions against a member state, which violates human rights. Nevertheless, the weaknesses of legal instruments at the national and regional level should not hinder the implementation of human rights to protect overseas migrant workers. One of the solutions is to strengthen the involvement of the ASEAN public (i.e. public participation) in promoting the protection of migrant workers. ASEAN public participation has been implemented by NGOs and CSOs in ASEAN countries. This approach should be actively promoted to fill the gap in the national legal instruments as well as ASEAN instruments pertaining to the protection of overseas migrant workers.

\section{REFERENCES}

\section{A. Books}

Fathor, Rahman, 2011, Menghakimi TKI: Mengurai Benang Kusut Perlindungan TKI, Pensil, Jakarta.

Manajit, Suchita and Na, Mai Thi Thanh Nga, 2011, Migrant Workers Rights to Social Protection in ASEAN (Case Studies of Indonesia, Philippines, Singapore and Thailand), Friedrich-Ebert-Stiftung, Pamplona.

Soekanto, Soerjono and Mamudi, Sri, 2003, Penelitian Hukum Normatif Suatu Tinjauan Singkat, Raja Grafindo Persada, Jakarta.

Soerjono and Abdurahman, H., 2006, Metode Penelitian Hukum, Rineka Cipta, Jakarta.

Sunggono, Bambang, 2003, Metodologi Penelitian Hukum, Raja Grafindo Persada, Jakarta.

\section{B. Internet Article}

ANTARA, "Kasus TKI Bermasalah Terbanyak Soal Gaji Tak Dibayar Majikan", http://www. antarakl.com/index.php/naker/1103-kasus- tki-bermasalah-terbanyak-soal-gaji-takdibayar-majikan, accessed on 28 December 2014.

ASEAN, "ASEAN Economic Community Blueprint", www.asean.org/archive/5187-10. pdf., accessed 8 September 2014.

ASEAN, "Statement of the Establishment of the ASEAN Committee on the Implementation of the ASEAN Declaration on the Protection and Promotion of the Rights of Migrant Workers", http://www.asean.org/communities/ asean-political-security-community/item/ statement-of-the-establishment-of-the-aseancommittee-on-the-implementation-of-theasean-declaration-on-the-protection-andpromotion-of-the-rights-of-migrant-workers, accessed on 30 July 2007.

Human Rights Watch, "Abuses against Female Migrant Domestic Workers in Indonesia and Malaysia", http://www.hrw.org/ reports/2004/07/21/help-wanted, accessed 8 
September 2014.

Kalayamitra, "Mekanisme HAM di ASEAN: Peluang Penegakan HAM di Tingkat Regional", $\quad$ http://www.kalyanamitra. or.id/2013/02/mekanisme-ham-di-aseanpeluang-penegakan-ham-di-tingkatregional/, accessed on 6 February 2014.

Mahidol Migration Centre, “Migrant Workers' Right to Social Protection in ASEAN: Case Study of Indonesia, the Philippines, Singapore and Thailand", http://www.ilo.org, accessed 8 September 2014.

Migrantcare, "Nasib Buruh Migran di Regional ASEAN", http://www.migrantcare.net/mod. php $?$ mod $=$ publisher\&op $=$ printarticle\& art $i d=1451$, accessed on 5 May 2014.

UN Women, "Managing Labour Migration in ASEAN: Concerns for Women Migrant Workers", http://asiapacific.unwomen.org., accessed 8 September 2014.

Universitas Udayana, "Tesis", http://www.pps. unud.ac.id/thesis/pdf_thesis/unud-1411791400890-bab\%20iii.pdf, accessed on 14 August 2013.

\section{Others}

Interview with Ayu, Head of Yayasan Dunia Viva Wanita (TKI Shelter Batam) Batam, 25 November 2013. 